\title{
酒と調 理
}

料理に酒が使われることは, わが国の清酒やミリン, 欧米のワインの 例を引くまでもなく䍃知のことであるが，それでは, 酒を料理に使うと なぜおいしくなるのか, 酒の中のどの成分が料理をおいしくするのか, どんな料理にはどんな酒を使えばよいかなどとあらためて問い直される と, 八夕と答に笨する。そこで, 食品研究家・評論家として知られる筆 者に,こうした問題に答えて頂くことにした。

\section{河野友美 \\ 大阪蕉英女子短大 \\ 河野食品研究所}

\section{酒と料理の味}

調理の際, 酒を用いることは, 広く各国で行われてい る。この意味は, 仕上がった料理の味に, 何かプラスが あるためである。では, どのような点でプラスがあるの だろらか。酒を用いたものと，用いない料理とを比較し てみると、どこかに差巽のあるのが味覚上はっきりとわ かる。しかし，それが，どらいら傾向のものであるかと いうことは，非常に判別がむずかしい。

では, 酒の何が, 調理の際に味に変化を与兄るのであ ろらか。まず, 考兄られるのは, 酒の主成分であるアル コールの影響である。ところが, みりんのよらに, アル コールを煮切るなど，ほとんど飛ばしてしまってから使 用するもの, 調理の最後にふりかけて然やすブランデー のようなものもあり, アルコールそのものが, 必ずしも 味に影響していないのではないかと思われるすのもあ る。つまり, 酒の調理への利用は, もっと広範囲の, 了 ルコール以外の成分も，かなり大きく影響を与えるもの であると考えることができる。

アルコール以外の成分として，味に影響を与えると考 えら礼るものは, 香り成分, 旨味, 酸味, 甘味, 橴味之 いったものではないだろらか。その中でも, 香りと酸味 などは，味を左右する大きなるのの一つであると考元て よいだろう。

\section{アルコールと料理の味}

調理の際アルコールを加えることで, 料理の味にはか なりの影響がある。とくに, 甘味と酸味がある場合, ア ルコールの味に対する影響が大きい。みりんを惹切った り,ブランデーを然やすなど, アルコールを飛ばした場
合でも，完全にアルコール分が料理の中からなくなるわ けではない。少量ながら残ったアルコールは, 料理の味 に影響するわけである。

では, どのようにアルコールは料理の味に変化を与え るのであろらか。第一にあげられるのは甘味である。ア ルコールは，甘味によってその刺激的な味がまるくなる ほか, 甘味が大変気持のよい感じのものになる利点があ る。カクテルなど, そのもっともよい例である。料理に 含まれる甘味が，アルコールが少量加わることで，その アルコールがかくし味となり，いわゆるくどい甘ったる さが消光る効果がある。しかし，はじめに含まれていた 甘味の濃さがあまり高いとさには, 大さな効果が期待で きないばかりか, よい味にはならないから、はじめの甘 味料の添加を, 調理時によく調整しておか叔ばならな い。

次にアルコールと酸味の関係であるが, これも, よい 味を出すのによい効果をもつ。とくに, 甘味がともに存 在するとき, 酸味, アルコール味が共に働きあって, や わらかな味となる。この酸は, 料理自体に含まれること もあるし, 酒に由来することるある。果実酒, 清酒, そ の他の款類酒では, 酒自体にかなりの酸をるつから, 当 然これが調理時に味に働らくはずである。その中でもブ ドウ酒がもっとも酸の効果が大きいのではないだろう か。この点では, ブドウ酒を調理に使用する際, 酸味の 強さが，大きく料理自体の味を左右しかねない。ただし 酸味は，あくまですアルコールとともにかくし味として 作用することが望むしい。なぜなら，酸味を呈すること を望まない料理に酸味を感じるのは, 料理の味としては 不合格だからである。 


\section{酸味と料理の味の関係}

酸味は，あんばいということばが古くからあるように 塩味をまるくする力をもっている。あんばいとは程梅で 塩味に梅酢が加わることで味のまるくなることである。 しかも, 料理のおいしさは, 塩加減といらことばであら わされるように, 塩味がソフトに感じることは, 非常に 料理を招いしくすることで意味が大きい。

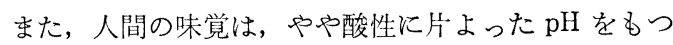
料理や食品を拈いしいと感じる。これ対して，アルカ リ側から, 中性付近の $\mathrm{pH}$ のものは, ね淮けた味として 味覚に感じる。そこで, 少量の酸が加わり, 料理の $\mathrm{pH}$ が，やや酸性に傾よるときは，料理の味がおいしくな る。料理人の間では, 酢をかくし味として用いることが 多いのもこの理由からである。

さて，酒との関係であるが，さきにも少し触れたよう に，酒そのものに酸をもっているものが多い。酒のもつ 酸が多いほどよいといらわけではないが, ある程度, 酸 をもった酒だと、この酸が $\mathrm{pH}$ の調節や，出んばいのた め飞働いてくれる。しかも, その酸の種類が異なれば, 塩味や，pH にひびく度合も自ずからちがってくる。そ れだけに，一がいに，どういう酒を用いれば，昧がどの ようになるとはいい切れない面がある。しかし，料理に 使う酒については, 蒝溜酒は別として, 一般に酸の状況 は無視することのできないものであろう。

\section{清酒と料理の味}

古くから，日本の料理では，調理の際に清酒を用いる ことが多い。また, 清酒を用いることで, 料理の味に深 味のでることも事実である。ところが，ひと口に清酒と いっても，アルコール分以外の各種の成分はかなり差異 がある。これが，料理の味に，相当に大きくひびいてく る。

清酒のちがいによる料理の味の差についてテストして みたところ, 同じ量の清酒を使っても, 清酒ごとの特性 により，かなり大きな差異のでることがわかった。Aの ものは, 吸物, ごはんものなどの味が非常によくなる半 面, 魚の生ぐさみなどに効果がない。ところが，Bにな ると, 魚の生ぐさみは消觉るが，めんやそばのつゆでは 味がくどくなりすぎる。また，Cは，一般に使用されて いる清酒の量を加えるとよくないが，半量炕すると非常 によい。Dのものは，味に対して，活とんどよくする効 果がないといったような状況である。

では, 清酒を飲んだときの, 甘口, 辛口と料理の味の 関係はどらかとしらべてみても，これもとくに関倸がな い。どちらかというと, やや辛口の方が，調理に対する
効果があるのではないかと思われるといった程度のもの である。

では, アルコール涯加と, 純米酒ではどうかをみると やや純米酒の方が調理上の效果があるよらであるが，こ れも, 必ずしも判然としない。同㥞に，特級，1級， 2 級の差もとくにみられなかった。

一方, 新しい清酒と，かんざましとでは，どちらも大 きな差はなく，俗に，かんざましを料理に使えといわれ ているのは本当であるようだ。

清酒それぞれの，組かい戌分值がわからない以上，一 体どういら成分が料理の味に影響しているのであるかは 今のところ不明である。たた，一般に，化学調味料的な 味の強い清酒は, 料理の味をよくしない傾向のあること だけはいえるようである。

このようにみてくると, 料理には清酒と漠然といって も，どの清酒を，どういら分是で調理に使用したかによ り, 清酒の調理に刘する評洒は大きな差琪がでてくるこ とになる。な技，調理に汪とんど効果のない清酒は，ア ルコール添加量が多く, 清酒醇造の際, 発酸に上り生ず る成分が少ないものではないだろらかと推定される。

\section{みりんと調理}

みりんは, 本来, 調理用の酒として, 飲用よりる, 調 理用として広く使われてきたものである。このみりんで あるが，一般には，甘味づけとつや出し用のように思わ れている。もちろん，このような効果も調理上あるが， このほかに，案外見落されているのが，魚臭などに対す る矯臭効果である。

みりんの矯奥効果がぜひ必要なため, 必ず使用されて いるのが，かまぼこなどの水産㸚り製品である。最近は その原料の大部分が，スケトウダラのすり身になったが 以前はサメが多く使用されていた。このサメは，魚肉中 に尿素など，分解により，非常な悪臭を出す成分があ る。そのため，サメのすり身を蒸すと，強烈なに打いが でる。ところが，みりんを，魚肉に対し，1,000 分 1 程 度加えて䓠すだけで，に拈いの恶さは消光，かま涪こ特 有の香りとなる。

このみりんの矯臭効果は，どの部分にあるのだろう か。竹内氏によると, みりんの不揮発部分にあり,こう じ菌の菌体自己消化生㦃物としてできてくるという。み りんは, 調理に使用の際, たいていは煮切って使用与る が, この操作によっても, みりんの有效成分はなくなら ないということだ。

みりんが調理に使用される際，その甘味成分も大きな 意味をるつ。一つは，甘味そのものの付与であり，もう 一つは, アミノカルボニル反応である。とく溞热し 
たときには，メラノイジンを生成し，キッネ色とこうば しい香りを発生する。

甘味は, 麦芽糖, ブドウ糖などの還元糖が主で, 砂糖 のような非還元糖とは買る。味も，砂糖のようにくどく ない。一般に, 料理に砂糖のよらな甘味が含まれると き，その甘味が，細かい味をかくし，材料のもち味を落 とす傾向がある。砂糖入りの料理では, その味は, 材料 のもつよさが生かされないといわれる理由もここにあ る。ところが, 関西風の含め煮などには, 必ずうすくち しょら油とともに使用される。おもしろいことに，みり んの甘味だと, 材料の風味は消されない。それどころ か，材料のもつ風味がひき立つのである。このあたり， みりんのどういう成分がどのように㗢くのかは，今のと ころ全く解明されていないといってよい。みずあめやブ ドウ糖を加えても，みりんのような効果はないから，お そらく, みりんそのものに含まれる何かと, 糖との関係 と思われる。

みりんの糖分は, メラノイジン生成にとって, 非常に 具合のよい還元糖である。とくに，しょう油のような， アミノ酸を多く含むものとでは, 簡単にメラノイジンを 生成する。メラノイジンは, 魚などの生ぐさみを消すと ともに，食欲を増す作用のある否りをもつ。また，きれ いなキッネ色と、ッヤもある。てり焼きなどよい例だ。

さらに, メラノイジンは, 抗酸化性が強く, 食品の保 存によい效果をあらわす。佃煮など，しょら油とみりん を加觉，加熱することでメラノイジンが適度に生成され るため, 塩分濃度とともに, 食品の酸化による劣化を防

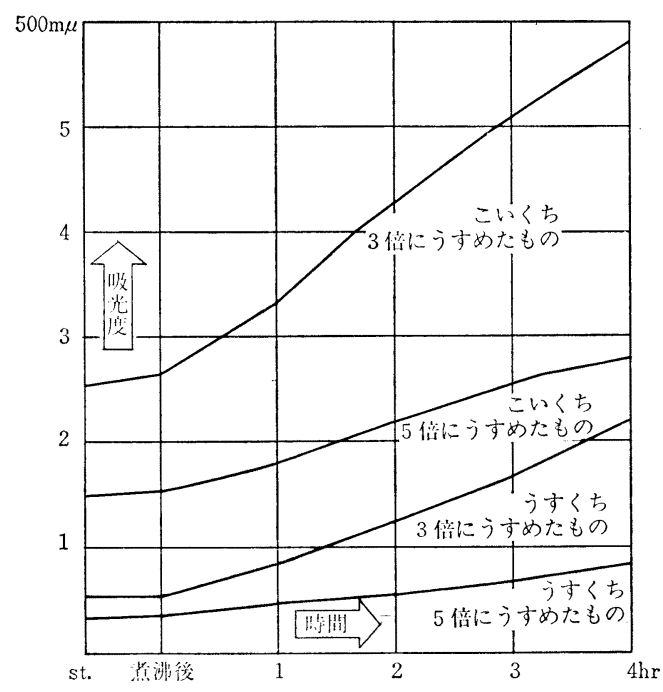

しょう油に，10\%のみりんを加え， 3 倍および 5 倍 にうすめ, 加熱したときの色の变化

(資料：キッコーマン酱油中央研究所)
いでいるものと思われる。また，煮物が，ただゆでたも のより，しょう油，みりんを加えたものの方が，時間が たっても変化しにくいのは，やはり，生成されたメラノ イジンによるものと考えてよい。

らすくちしょう油とみりんを加えて含め煮などすると きは, しょら油のアミノ酸とみりんの糖によるアミノカ ルボニル反応により, 適度の色の増加と, それによる風 味の強化もある。しょう油にみりんを加え, 逆流冷却器 を付けて液量を変化させずに加熱した場命の色の変化は 図の通りで, 明らかに, 反応の進んでいるのがわかる。

\section{材料と酒の相性}

調理する材料により，酒の相性があるよらに思われ る。もらろん, 全く合わないといらものは大へん少ない が，よりよい相性というのは, 案外あるものだ。

たとえば，清酒を例にあげると，肉，とくに，しょう 油を使用しない料理には，他の料理に使用したとさほど の効果がない。ところが, 肉の場合, ブドウ酒の方がよ りよく味を変化させる。うどんのかけ汁の場合は, ブド ウ酒よりも，みりん，酒の方がよりよい味がでる。野菜 をしょら油で煮る場合, シェリー酒よりも, みりん, 清 酒の方がよいといったぐあいである。

このような相性は, 一体何からでてくるのであろう か。今のところ, 調理科学の分野では, この点について は，ほとんど研究されていないといってもよい。しか し, 調理の上に拈いて, これは非常に重要なことであ る。なぜよくあらのか。どのような成分と, 何がどのよ らになるのかといらことがわかれば，もっと，酒と調理 について系統的に考えていくことがでさるはずである。

もちろん, 食品材料の成分といらのは, 化学製品とは異 り, 大へん構成が複雑である。同じ品種のものでも, と れた時と, 場所により, かなりの相違がある。このよう なるのと, 酒の方でもかなり複雑な成分をもっているか ら，その間の関係は，大へん複雑にならざるを得ない。 とはいっても, 酒と調理, とくに, どの成分が有効なの であるかといった研究は，もっと進められてよいもので あると思ら。

とくに，日本の酒である清酒については，個性がかな りあるにもかかわらず，料理との関係はあまり明らかで はない。もちろん，酒が嗜好品であるといってしまえば それまでだが，欧風料理に対するブドウ酒のあり方とは 大へんなちがいがある。欧風料理の場合，ブドウ酒は， 料理に使うものと, 飲むるのとに, かなり強い関連性が ある。とくに，ソース，スープなどに使用するブドウ酒 の量は多く，ブドウ酒が，これらのものの味の大きなウ エイトを占めているといってもよいくらいだ。そのため 
おのずと，それにあったブドウ酒が選ばれていくといっ てもよいだろら。

ブドウ酒ほどではないにしても，さきにあげたように 清酒といっても, 決して画一的なものではない。とくに 調理への使用に当っては, 清酒ごとに, 個性がでてく る。このような事実があるとすれば, 当然, あっと, そ の成分と食品材料, あるいは調理操作の中での変化とい
った関係は解明されなければならないのではないだろう か。

現在, 日本の食品は, 今までのように, 新鮮で風味の よいものはほとんど姿を消している。このような材料を 調理するのには, 風味を高める酒の存在は大へん重要で ある。それだけに，酒と調理との関係が，もっと興味を もたれてよいのではないだろらか。
- 執筆者紹介（順不同・敬称略）

\section{梅田 勇雄 (Isao UMEDA)}

明治 36 年 10 月 7 日生（勤務先とその所在地）〈有〉調味 食品コンサルタント協会 東京都新宿区北新宿 2-5-25134 (略歴) 昭和 5 年東京大学 農学部 農芸化学科卒, 同 年キッコーマン醬油〈株〉入社同試験所勤務, 33 年停年 退職, 同年日本醬油協会常務理事, 48 年〈財〉日本醬油 技術会理事長, 51 年〈有〉調味食品コンサルタント協会 （賞罰）昭和 26 年恩賜発明賞を授けらる，30 年農林大 臣賞を授けらる，31 年紫綬褒章を賜わる，32 年農学博 士， 48 年勲四等旭日小綬賞を授けらる(著書) 醬油 昭 和 24 年出版 三共出版〈株〉, 醱酵食品〈微生物工学講座 第 8 巻〉共立出版〈株〉, これからのしょう油 43 年出版 〈財〉日本醸造協会

\section{有馬啓 (Kei ARIMA)}

大正 5 年 9 月 19 日生 (略歴) 昭和 16 年東京大学農学 部農芸化学科卒, 17 年三井化学〈株〉入社, 22 年東京大 学農学部農芸化学科発酵学教室助教授, 33 年同教授 (研 究テーマと抱負) 微生物の生成する新生理活性物質, 微 生物による環境浄化, 異種 DNA の微生物への尊入（趣 味) 飲酒談笑, 美術鑑賞, ゴルフ

\section{鈴木 明治 (Mieiji Suzuki)}

明治 40 年 8 月 21 日生（勤務先名とその所在地）東京 農業大学 世田谷区桜丘 1-1-1 (略歷) 東京大学農学部 農芸化学科卒, 国税庁醸造試験所所長を経て, 現在東京 農業大学教授（抱負）晚年を静かに生きることだけ（趣 味）無芸大（?）食。適飲。

\section{梅津伊兵衛 (Ihee UMEZU)}

昭和 7 年 2 月 23 日生（勤務先名とその所在地）米鶴酒 造〈株〉山形県東置賜郡高唣町二井宿 1076 (略歴) 昭
和 30 年東京農工大学農学部農芸化学科卒, 同年米鶴酒 造〈株〉社長に就任今日に至る（現在の仕事の内容）米 鶴酒造〈株〉社長〈企画・技術担当〉第三次近促山形県担 当委員 (抱負) 清酒の口あたり, ワインの味, ウイスキ 一の酔心地を超越した清酒を造り，世界醇造酒品評会で 清酒が優勝すること（诹味）うまい食物・らまい领物を あさること。音楽, 飛行機, ○○本の収集

\section{奥田 教広 (Norihiro OKUDA)}

大正 2 年 2 月 26 日生（勤务先名とその所在地）全国醸 造機器工業組合 港区芝琴平町 26 田口ビル (略歴) 昭 和 11 年北海道帝国大学農学部農芸化学科卒, 同年東京 税務監督局鑑定部, 18 年仙台財務局, 27 年札幌局, そ の後仙台, 広島, 大阪各局を経て 45 年東京局で退官(抱 負）醇造業の規模に応じた各種醇造機械の開発のお手伝 い（趣味）なし〈農学士の最後と思い家庭園芸に精を出 そうとしたところ, 隣のおばあちゃんの本格的技術に辟 易，全部芝生にした次第〉

\section{河野 友美 (Tomomi KONO)}

昭和 4 年 2 月 1 日生（勤務先とその所在地）〈主〉河野食 品研究所〈所長〉大阪市東淀川区瑞光通 6-12 コーポ 606〈兼〉大阪薰英女子短期大学〈教授〉 大阪府攝津市正 隹 1 丁目（略歴）25 年関西学院専門学校理工専門部食 品化学科卒, 同年大阪市立大学家政学部助手, 33 年浪 速短期大学保育科講師, 40 年大阪薰英女子短期大学助 教授, 43 年同 教授, 38 年河野食品研究所独立（現在 の仕事の内容）食を通じての生活文化，とくに嗜好と文 化の研究, および調理科学, 食品調理器機の開発（抱 負) 調理形態と住宅構造の関連にもとづく都市構造（趣 味）交通機関をのりまわすこと，とくに飛行㙨。絵画

(以下 506 頁) 